\title{
The digitization of the economy and the remodeling of the marketing strategies
}

\author{
Constantinescu Eleonora Mihaela \\ Faculty of Marketing \\ "Dimitrie Cantemir" Christian University \\ E-mail: mihaelaconstantinescu68@yahoo.com \\ Marinescu Gheorghe \\ Faculty of Marketing \\ "Dimitrie Cantemir" Christian University \\ E-mail: ggmarinescu@yahoo.com
}

Abstract: The informational society determines, on the strength of new communication and information technologies, a profound transformation of the exchange relationship. This enforces the building and the acceptance of a new paradigm viewing marketing, which affects the management not only by promoting strategic marketing, but also by taking into account new types of marketing like e-marketing and cybermarketing (types of marketing that were born thanks to the new communication and information technologies)..

Keywords: informational society, digital economy, marketing, communication and information technologies.

The remodeling of the exchange relations in the modern economy made marketing as a primary strategy of any company that has to correlate it's offer with the needs of the consumers, in order to gain profit. We may say that the first decade of the 20th century has set the economy into a marketing era (Ristea, Valeriu, 2010).

In the opinion of P. Gregory (Hrebiniak), a lot of changes have taken place during the marketing era and he divided them into three stages:

- customer centricity, a time when marketing represents "the action of research of the customer's needs which allows on one hand, the correlation between the offer (product, distribution, prices) and the demand; on the other hand, informing the customer through the use of publicity" (Lendrevie, Lindon, 1997). At this stage, we may notice the action of market research followed by the interaction with the customer through marketing.

- both customer and environmental centricity. This dual-concentration tendency became obvious during the $60 \mathrm{~s}$ and the $70 \mathrm{~s}$, when the ideas of environmental protection and sustainable development began to stand out. The concepts of "social marketing" and "assessment marketing" were born.

- Mega-marketing implies a wider perspective over marketing, taking into account the concept of customer satisfaction, which no longer means "just profit", but both the protection of the customer's rights, interests and the understanding of the company's resonsabilities towards the environment. 
I am sure that the exchange relationship will evolve due to the impact of the communication and information technologies from the digital age, which will ensure the survival of the companies that will speculate the new highly potential field of needs that will be generated in time.

All companies are aiming to survive in the market in nowadays and in the days to come. On both the medium and the long run, the success of the companies will be a consequence of their reaction to the competition and to the changes of the customers needs. Also, to gain profit, companies will have to acknowledge the market opportunities, avoid unnecessary risks and learn how to motivate their staff to become more efficient. The way so that all these come true, a company must think and act according to a strategy.

There are a few authors (Hamel, Prahalad, 2008) that take the two different types of marketing (strategic marketing and operational marketing), connect them together and throughout synergy, they name it as the basic company strategy. J.J. Lambin says that strategic marketing analyzes the current market needs, the relation between product and market, the both real and potential market segments, the advantage of having competition and the product's circle of life. Strategic marketing has the purpose to organize a plan to ensure the company's efficient growth.

Operational marketing concerns firm actions in order to secure the promised (financial) turnover, using the most efficient sales ways taking low costs into account. Operational marketing consists in a plan for the marketing funds made in correlation with both the marketing and the general strategies of the company (Kotler, Castilione, 2009).

To others (Lendrevie, Levy, Lindon, 2006), the operational marketing implies postproduction marketing actions, such as organizing a marketing plan, advertising, sales, post-sales, distribution and product control. On these terms, strategic marketing is a pre-production stage which puts it in an order, before the other stages like sales, distribution or advertising. The strategic marketing follows the marketing study, a marketing action that covers a full analysis of the market (company's environment, consumers behaviour, competition).

The entrepreneurs are dealing today with a complex economic reality due to a very large dynamics, where they have to understand and anticipate the effects of both technological and economic globalization at the company's level. They have to properly react to the deep changes of the consumers behaviour, generated by the changes of the demographic structure (the aging of the population, the growing number of bachelors or single-parent families). Other influences are the fragmentation of the market and the discovery of new customers needs, generated by the growth of both the level of information and the level of education. All of these above are being caused, also by the extension of the retail networks, franchise networks and the new communication and information technologies. As a result, these two entities indicate the market's evolution in the contemporary economy, globalization, new communication and information technologies and also new types of relations in the business world. In this context, the businessmen have fought these last few years with the fast expanding economical crisis at a global scale. This determined Philip Kotler and J.A. Casilione (Kotler, Castilione, 2009) to create 
a new type of marketing based on the idea that ,the excesive turbulence with its effect of chaos, risk and uncertainty represents now the only normal status of the industries, markets and also companies".

If the most authors state that marketing has a strategic role in the working process of any company, then this implies the need of some clarity over the terms of strategy, plan and politics. J. Lendrevie, J. Levy and D. Lindon (Lendrevie, Levy, Lindon, 2006) say that strategy, ,is the union of all actions used to reach a certain goal against any compentition", which brings an aggresive status to a company.

The plan has a more operational meaning and it concerns ,a number of accurate actions, with the mentioning of the terms and costs, the discription of the ways of action and also the responsabilities".

In order to separate these terms at a company's level, the three authors have created the term of politics, which means ,,a number of principles and decisions made and written before any other activity, for a certain period of time, so that certain goals may be reached".

I believe that the notion of strategy, even if it has military origins, it can be useful in economical language, with lesser hostile goals of eliminating competiton from the market and more positive purposes for leading the market. The context of globalization of new communication and information technologies generates new needs. Under the impact of new technologies, the economy and also the man himself commute into a digital universe, a virtual reality, discovering new types of needs which will lead to the creation of new markets.

As a result of the new communication and information technologies, the changes of the economic reality called for the founding of a new strategic paradigm.

The challenges of contemporary economics push entrepreneurs to accept a new strategic paradigm (Gregory, 1996) that will grant them an evolution: from the redesigning of their activities to rewriting their strategies, from organized transformation to commuting their areas of activity, from the battle for a slice of the market to the research of a new type of opportunities. As far as the "new future" is concerned, the new strategic paradigm covers the transitions from the learning strategy to the shifting strategy, from the positioning strategy to the predictive strategy and last but not least, from strategic plans to strategic architecture. The two authors vision regarding the shift for the future, describes that the company must switch from the aptness strategy to the flexibility strategy and also from the resources allocation strategy to the accruement and efficient use of the resources.

A company's biggest challenge after adopting a new strategic paradigm becomes the action of "reading" (Kotler, 1986) the future before others. The shift that has to be made is from the competition over an area to the competition over the purpose of influencing future market research; also, from the battle of the products to the battle for supremacy of the best proficiency; from the growing market share to the growth of market knowledge; from narrowing the time of distribution to a faster conquer of the market.

The remodeling of the strategy notion is seen also in advertising new operational concepts, such as "strategic architecture"; collocation explained by G. Hamel and C. K. Prahalad 
as "a structure model of new functions for gaining skills and for the reconfiguration of the client reports" (Balaure, Adascalitei, Balan, Boboc, Catoiu, Olteanu, Pop, Teodorescu, 2000).

The new market challenges, the resizing and the restructure of the strategic marketing, make it necessary the training of an elite management team, capable of absorbing a new type of economical knowledge, capable of controling a larger amount of information, finding and applying complex solutions in order to adapt to these new requirements, also to the new customers behaviour.

Ana Lucia Ristea and Valeriu Ioan Franc (Ristea, Valeriu, 2004) talk about three levels of strategy:

- corporate level;

- business activity level;

- $\quad$ working level.

At a corporate level, marketing is not very important, but at the business activity level, marketing plays a center role by identifying the competition's strong points and by conducting the company's policy. At the working level, the marketing strategy is connected with other company's functions and it uses the marketing mix to accomplish all the strategic goals.

In order to train a specialist in marketing, it is necessary the knowledge of the basic steps of compiling a marketing strategy; otherwise that manager, with no vision, will not be able to ensure the success of his company. To some authors (Dubois, Jolibert, 1994), the compiling process is ensuant interactive, creative and frequentative. Interactive means that the marketing specialist works with the people responsible with production, finances, distribution and human resources. The need to both survive and strive on the market is that all personnel must work in synergy. Creative refers not only to the ability of innovating but also to choose the most suitable strategy in order to motivate the buyer to make a purchase, despite the competition's products. Frequentative means that the strategy can be adjustated in time, according to any changes in the market or in the company.

I believe that compiling a marketing strategy is also an integrating process because all the other strategies within the company are strictly connected to it, representing the foundation of the whole company's strategy.

In the vision of the two authors (Shermer, 2013), the main stages of compiling a marketing strategy are:

- analysis-diagnosis;

- $\quad$ setting goals;

- choosing the basic strategic options; 
- defining and evaluating the marketing mix;

- compiling and deploying the short term action plans.

The analysis-diagnosis stage consists in market analysis and internal analysis, followed by compiling a diagnosis which will represent the foundation for the second stage, goal setting. Eventually, the third stage is choosing the right strategic plan, the right goals, the positioning of the company, the budget and the priorities. The fourth stage, concerns the formulation and evaluation of the marketing mix which consists in forming the product, price, distribution, communication and sales strategies. This stage has been exposed by Ana-Lucia Ristea and Valeriu Ioan Franc (Ristea, Valeriu, 2004). Each of these plans represent a role in the basic and important strategies. The product strategies incorporate all strategies about the range of the product and the life cycles of the products, the strategies used to innovate products, as well as strategies that influence the quality and performance of the products (Lendrevie, Lindon, 1997).

The pricing strategies incorporate all strategies that are form in the use of the new launching products, costs analysis, demands and competition.

The distribution strategies systematize the basic "push" and "pull" strategies, communication channels which are put in value by advertising strategies, public relations and sales. The sales strategies are compiled on the basic running of the sales force in co-operation with actual and potential customers.

Only by compiling and correct deployment of a high achieving marketing strategy, a company will diminish the market risks. But this correct use, by itself, doesn't ensure success on the market. "In other words, the strategy models must not be used just because. Every ingredient, combined with experience and knowledge, used at the right moment, can help companies to reach the wanted success." (McCarty, Perrault, 1987)

The success of a marketing strategy depends on the way it's being put into action, a complex process which uses all operating and decision mechanisms, all management skills, all preparing actions and last but not least all deployment actions (deployment takes a longer time than the preparation) (Steven ten Have, Wouten, Stevens, Elst, Marcel, Pol-Coyne, 2008).

Inspired by L.G. Hrebiniak, Ana-Lucia Ristea and Valeriu Ioan Franc (Ristea, Valeriu, 2004) have identified eight areas where it is convenient to act in order to have succes in deploying the marketing strategy:

- to set up a model that will guide all deployment decisions and actions;

- a correct use of the strategy in the deployment activity;

- an efficient administration of any changes that might happen in the company;

- a correct approach of the ideas of "power" and "influence" inside the company; 
- setting up departments responsible with communication within the team and establish each responability;

- to bring forth testing, feedback and control entities;

- to inspirit actions that lead to setting up a culture that supports change;

- $\quad$ put into action a management plan oriented to the deployment and growth of a leadership spirit. (Ristea, Valeriu, 2010)

To sum up, we find ourselves in a moment of evolution of the exchange relations, when those who wish to find customers for their services and products; have to possess great knowledge of demand, of microeconomics, of macroeconomics in order to strategically deploy corectly in the market. I must say that the market challenges companies that know how to manage risks, so that the fortified entrepreneur spirit will adapt to all changes generated by the globalization of the communication and information technologies.

\section{References}

1. Ristea A.,L., Valeriu, I., F., 2010, Marketing strategic, Expert Publishing House, Bucureşti,

2. Hrebiniak, G., L., Strategia în afaceri. Implementarea si executarea eficientă (translate), ALL Publishing House, Bucuresti,

3. Lendrevie, J., Lindon, D., 1997, Mercator. Theory et practique du marketing, 5 Edition, Paris: Editions Dalloz,

4. Hamel, G., Prahalad, C., K., 2008, Competiţia pentru viitor (translate), Meteor Press, Bucuresti,

5. Lendrevie, J., Levy, J., Lindon, D., 2006, Mercatot, 8 Edition, Paris: Dunod,

6. Kotler, Ph., J.A. Castilione, Chaotics, 2009, Management and marketing in turbulent period (translate), Publică Publishing House, Bucuresti,

7. Lambin, J., J., 1999, Le marketing strategique. Du marketing a l'orientation-marche, 4 Edition, Paris: Edisence International,

8. Gregory, P., 1996, Marketing, 2 edition, Paris: Edition Dalloz,

9. Kotler, Ph., 1986, Principles of Marketing, Third Edition, Prentice-Hall, Inc, Englewood Cliffs, New Jersey,

10. Balaure, V., Adascalitei, V.,Balan, C., Boboc, S., Catoiu, I., Olteanu, V., Pop, Al., N., Teodorescu, N., 2000, Marketing, Uranus Publishing House, Bucuresti, editia a II a 
11. Ries Al, Trout J., 1997, Marketingul ca razboi (traducere), Editura Antet, Bucuresti, 1997

12. Dubois, P., L., Jolibert, A., 1994, Marketing. Teorie si practica (translate),. Universitatea de Stiinte Agricole Publishing House, Cluj-Napoca,

13. Shermer, M., 2013, The inteligent of market (translate), Curtea Veche Publishing House, Bucuresti,

14. Hill, E, O`Sullivan, T., 1997, Marketing (translate), Antet Publishing House, Bucuresti,

15. E.J. McCarty, E.J. Perrault Jr, 1987, Basic Marketing (Irvin, Homewood, III, Ninth Edition)

16. E.J. McCarty, E.J. Perrault Jr, 1987, Basic Marketing (Irvin, Homewood, III, Ninth Edition)

17. Kotler, Ph., 2003, Kotler despre marketing. Cum sa cream, cum sa castigam si cum sa dominam pietele, Brandbuilders Publishing House, Bucuresti,

18. Demetrescu, M., C.,1999, Analiza inter şi intrafuncţională de marketing, „Buletin de marketing", nr 2

19. Have Steven ten Have, Wouten, D., ten, Stevens, F., Elst, Marcel van der, Pol-Coyne, F., 2008, Modele de succes pentru managementul firmelor (traducere), Andreco Educaţional Group Publishing House, Bucureşti,

20. Drăgănescu, M.,2003, De la societatea informaţională la societatea cunoaşterii, Tehnică Publishing House, Bucureşti, 